\title{
THE DEVELOPMENT OF ISOLATED RESTING SPORES INTO AUXOSPORES IN DITYLUM BRIGHTWELLI (WEST.)
}

\author{
By F. Gross \\ From the Plymouth Laboratory and Dept. of Zoology, Edinburgh University
}

(Text-figs. I-2)

The resting spores of Ditylum are formed as a result of a peculiar kind of plasmolysis of the protoplast (Gross, I939); they are small spherical bodies lying inside the old cell wall. Since one-half of the cell wall is only slipped over the other half it is likely that in the sea they might become separated and the resting spore proper would drop out of the shell. In a previous paper (Gross, I937) it was stated that in old cultures a considerable number of resting spores could be found outside the parental shells, and when transferred into fresh culture medium they only expanded in volume. Since then more attention has been paid to such isolated resting spores and the formation of new cell walls has been frequently observed.

In order to obtain sufficient material resting spores formed in crowded cultures under laboratory conditions were removed from the shells. This was done under a low-power binocular with the aid of micro-glass needles, the points of which were bent at 90 degrees. The bent end of the glass needle was pressed against the shell perpendicularly to the long axis a short distance from the centre. One-half of the shell usually gave way and fell aside and the resting spore, if situated in the centre of the cell, dropped out. If it was lying excentrically it could be "squeezed out" by slight pressure with the needle or by slight agitation with a pipette.

When placed in fresh culture medium the isolated resting spore (Fig. Ia) started germinating. The process is essentially the same as that occurring inside the shell, but, owing to its absence, the germinating resting spore has a very unusual appearance. At first a varying number of very fine protoplasmic processes are sent out in all directions (Fig. $\mathrm{I} b$ ) lending the spore a superficial resemblance to a Heliozoan. These processes when formed inside the parental shell connect the resting spore with the cell walls. This stage was reached by most cells in about $\mathrm{I}-3 \mathrm{hr}$. Then the cell flattened down and the protoplasmic processes became more conspicuous. Chromatophores passed along these processes and the protoplast gradually expanded (Fig. Ic). New "pseudopodia" and branches of the old ones were formed and others absorbed, the cells showing a striking resemblance to certain amoebae. In the course of one to two days the cell body became bigger and the "pseudopodia" 
correspondingly shorter until the cell assumed a spherical shape again (Fig. Id). Of several hundreds of resting spores kept under close observation not a single one developed into the bigger spherical body by simple expansion; all passed through the "amoeboid" stage.

As regards their structure these spherical bodies resembled auxospores (Gross, I937) in every respect. But they very often adhered to the bottom of the watch glass and in most instances only developed when they were gently

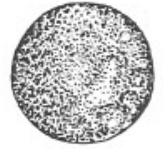

$a$

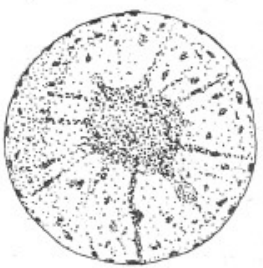

$d$
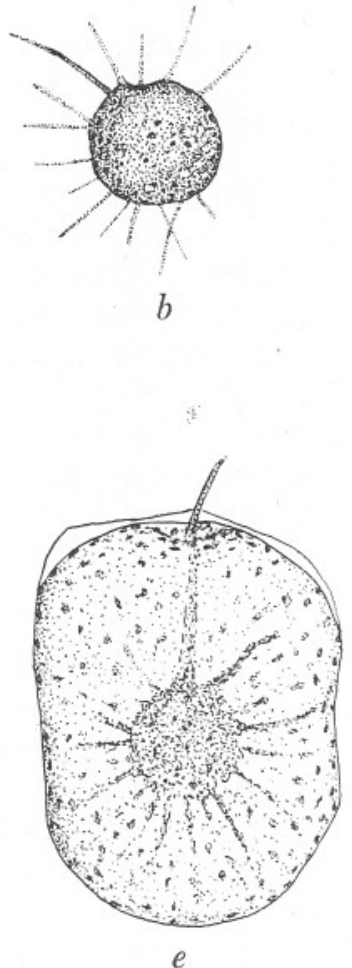

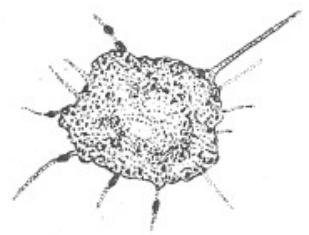

$c$

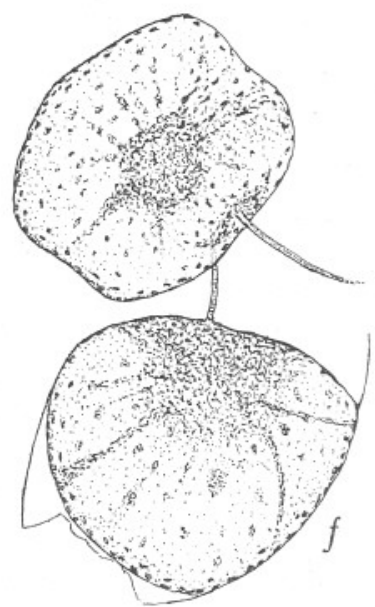

Fig. I. $a-f$ were traced from photographs; $a$, resting spore separated from the shell on May 3 , I2.45 p.m., photographed at 2.45 p.m.; $b-f$, stages of germination of the same resting spore; $b$, photographed at 6 p.m.; $c$, on May 6 ; $d$, on May $7 ; e$, on May'Io; $f$, on May II.

detached from the glass. (This was done by directing a current of water from a pipette towards them.) Once they were freed they developed in the same way as auxospores. The cell elongated and became more cylindrical and in about $24 \mathrm{hr}$. one valve was formed (Fig. Ie) and in another day the second. After that the cell started dividing (Fig. If).

The result of this kind of development is that the cell derived from the isolated resting spore and its progeny always possess a very large diameter. 
An isolated resting spore regularly passes through the auxospore stage during development. Whatever the diameter of the cells may be that have formed the resting spores, these always develop into very broad cells of a diameter of $80-100 \mu$. In one instance the average diameter of twenty-five cells that had undergone resting spore formation $(a)$ was $4 \mathrm{I} \cdot 3 \mu$. One resting spore from this sample was isolated and the average diameter of twenty-five cells developed from it was $103.4 \mu(b)$; that of twenty-five cells developed from auxospores in the same culture $85.0 \mu(c)$. The cells of $a$ varied in diameter from 39.5 to $44 \mu$; those of $b$ from $88 \cdot 5$ to Io9 $\mu$. Both $a$ and $b$ originated from one cell each. The twenty-five $(c)$ cells were taken from a colony of broad cells produced in the same culture as $a$. The colony had probably originated from several auxospores, and the cells showed a wider variation in diameter, viz. from 70 to $127 \cdot 5 \mu$.

In this experiment the diameter of the cells which originated from the isolated resting spore was more than twice that of the parental cell. When resting spores of narrower cells were isolated the difference was larger still.

"Artificial" resting spores (Gross, I939) induced by the action of $3.3 \%$ sodium chloride solution developed in a very similar manner when isolated from the shell and placed in culture medium. Fig. $2 a$ shows one such resting spore inside the shell and Fig. $2 b-f$ are typical stages of its development after isolation. This particular cell was slightly injured when being removed from the cavity slide after the drawing of Fig. $2 e$. The second valve did not develop for some days and the subsequent division was abnormal. In other experiments most of the cells developed quite normally and gave rise to large cell colonies. Like the natural resting spores the isolated "artificial" resting spores tended to adhere to the glass in the auxospore stage, and the "auxospores" had to be detached before further development could take place.

In one instance twelve "artificial" resting spores were isolated from the cell walls. The parental cells measured from 30 to $42 \mu$ in diameter. Nine of them developed into auxospores and then into broad cells which gave rise to an actively growing culture After 20 days twenty-five cells were measured; their diameter varied from 70 to $95 \mu$ with an average of $80 \cdot \mathrm{I} \mu$.

Vegetative cells gradually plasmolyse in the absence of light and the resulting resting spores only recover, or germinate, when exposed to light. It has been found previously that "artificial" resting spores, even when placed in the dark, are capable of a temporary partial recovery (Gross, I939). Isolated "artificial" resting spores when kept dark may develop as far as the auxospore stage.

In one experiment a sample of Ditylum was transferred into a solution of $0.6 \mathrm{M} \mathrm{NaCl}$, to $100 \mathrm{ml}$. of which $5 \mathrm{ml}$. of $M / 5 \mathrm{Na}_{2} \mathrm{HPO}_{4}$ was added and twenty of the resulting resting spores were isolated from the shells and placed in culture medium in a dark box. After I9 hr. one cell was amoeboid; the others had formed auxospores by then. However, most of them were remarkably small. All auxospores were gently detached from the glass. During the 


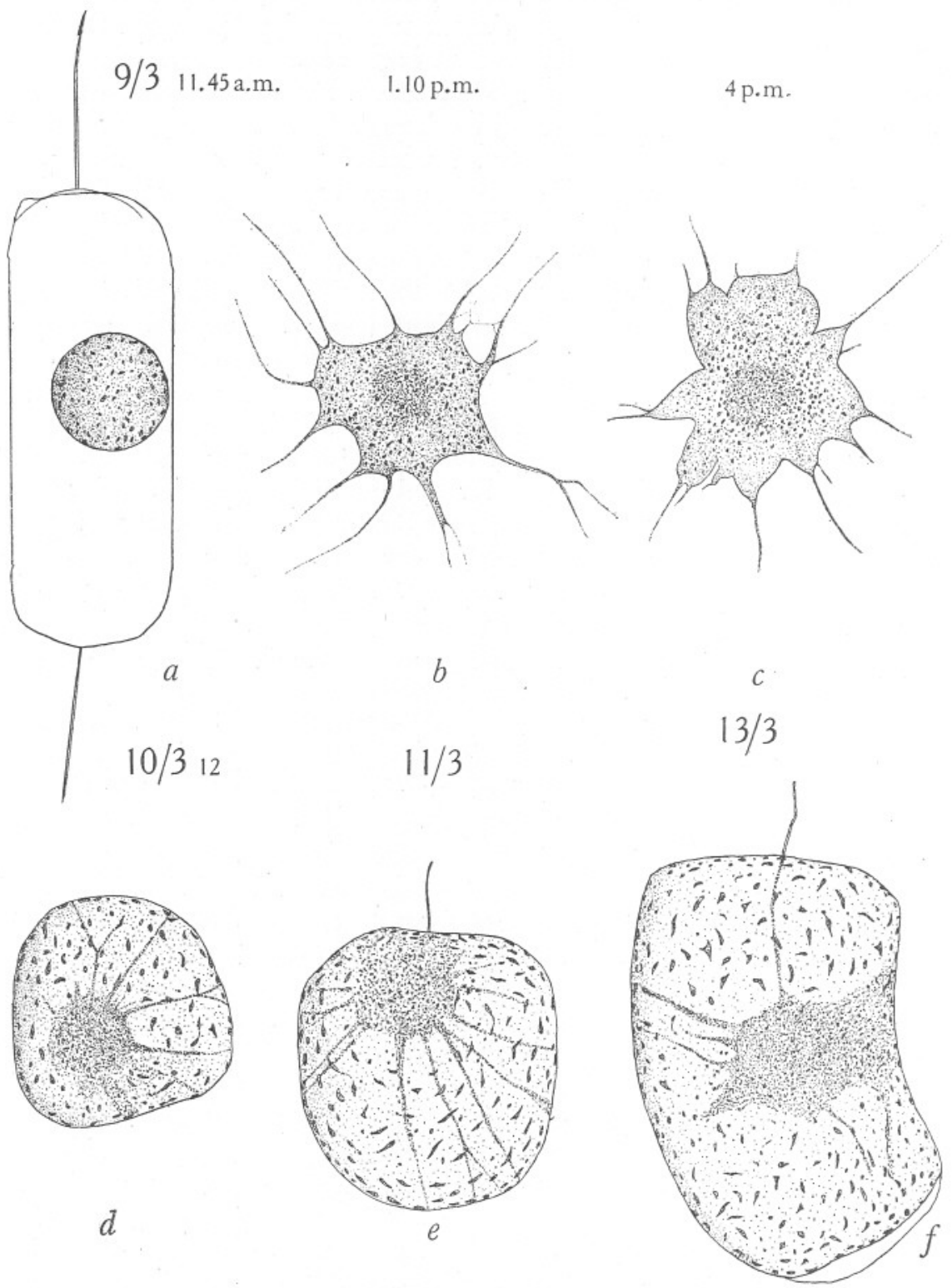

Fig. 2. a, "Artificial" resting spore formed in $3.3 \% \mathrm{NaCl}$ solution. The shell was removed and the spore placed in culture medium at II.52 a.m.; $b-f$, stages of development of the same resting spore. $\times 400$. 
following $24 \mathrm{hr}$. no further development took place except that the one amoeboid cell had by then also formed an auxospore. The day after only one fairsized and three small auxospores were present while all the others had become amoeboid again. Seven days later the amoeboid cells had only very short "pseudopodia" and there was only one auxospore left, which had the protoplast contracted inside the auxosporal membrane. The dish was then placed on the window bench in light. After five days there were six groups of six, thirteen, four, five, eight and twenty-one broad cells respectively. Thus at least six cells had recovered and started multiplying again.

This experiment shows that isolated "artificial" resting spores kept in the dark, behave similarly to those inside the parental shells. The small auxospores correspond to the short protoplasts forming a secondary valve (Gross, I939). Complete recovery, involving the formation by the auxospore in the dark of a new shell, was never observed. That the majority of resting spores only developed into small auxospores is probably due to the necessity of expending energy for the maintenance of the cell turgor.

The gradual decrease in the cell diameter of a diatom population is normally counteracted by the formation of auxospores. This also takes place in Ditylum cultures whenever the cell diameter has decreased beyond a certain size (Gross, 1937). The above observations show that the formation of auxospores by the extrusion of the protoplast from narrow vegetative cells is not necessarily the only mode whereby the size of the diatom may be regulated. It seems very likely that in nature too a considerable proportion of resting spores become separated from the shells when sinking down to greater depths. Their subsequent germination would also lead to the formation of broad cells. The fact that isolated resting spores always develop first into auxospores and then into cells of about maximum diameter indicates that the size of a centric diatom is imposed upon the cell by the structure of its cell wall and the resulting peculiar mode of cell division. The protoplast as such is always capable of growing out into a broad specimen once it is liberated from its enclosing siliceous armour.

In the sea the period from one auxospore generation to another may last one year or, in some species, even two to five years (see Fritsch, 1935, p. 6I7). In cultures auxospore formation has been repeatedly found to take place only in diatoms whose diameter has decreased to a certain size. In Ditylum cultures auxospores only occur in populations of less than $45 \mu$ diameter. However, resting spores formed by cells of 50-70 $\mu$ diameter when liberated from their shells developed into cells of 90-IIO $\mu$ diameter. Therefore, in studies concerned with changes in the size of diatoms from plankton samples of certain areas (Wimpenny, 1936; Garstang, 1937) the possibility will have to be taken into account that the appearance of broad cells may also be due to the germination of isolated resting spores. 


\section{REFERENCES}

FrITSCH, F. E., 1935. The Structure and Reproduction of the Algae. Cambridge.

GARSTANG, W., I937. On the size changes of diatoms and their oceanographic significance. Fourn. Mar. Biol. Assoc., Vol. xxiI, pp. 83-96.

Gross, F., 1937. The life history of some marine plankton organisms. Phil. Trans. Roy. Soc., B, Vol. ccxxvirI, pp. I-47.

- - I939. The osmotic relations of the plankton diatom Ditylum Brightwelli (West.). fourn. Mar. Biol. Assoc., Vol. xxiv, pp. 381-4I5.

WIMPENNY, R. S., I936. The size of diatoms. I. The diameter variation of Rhizosolenia styliformis Brightw. and $R$. alata Brightw. in particular and of pelagic marine diatoms in general. Fourn. Mar. Biol. Assoc., Vol. xxI, pp. 29-60. 